\title{
Kaksi kuningasta Urho Kekkonen Kari Suomalaisen pilapiirroksissa
}

\section{Kari, Kekkonen ja uusi aika}

Tämä katsaus perustuu Kari Suomalaisen vuosina 1950-1986 Helsingin Sanomissa ja Viikkosanomissa julkaistuihin Urho Kekkosta käsitteleviin pilapiirroksiin. Kari Suomalaista - tai Karia, millä nimimerkillä hänet tunnettiin - voi hyvällä syyllä kutsua Suomen kautta aikojen merkittävimmäksi pilapiirtäjäksi. Hänestä tuli 1950-luvun alussa Helsingin Sanomien pilapiirtäjänä yksi näkyvimmistä Urho Kekkosen kriitikoista. Muiden vaietessa Kari jatkoi. Katsauksen empiiriset tutkimustulokset perustuvat laajan aineiston läpikäymiseen ja luokitteluun hyödyntämällä sisällönanalyysin menetelmiä. Karin pilapiirrokset on asetettu oman aikansa kontekstiin ja aiemman tutkimuksen teoreettiseen viitekehykseen.

Karin pilapiirrokset luovat aikalaiskuvan Urho Kekkosen aikakaudesta ja niistä poliittisista ja yhteiskunnallisista voimista, jotka ohjasivat kehitystä. Pilapiirrokset eivät koskaan edusta objektiivista totuutta, vaan on otettava huomioon niiden luonne subjektiivisena ja kärjistävänä näkemyksenä (Navasky 2013, 35; Ylönen 2001, 17). Karin Kekkos-kuvaa tutkittaessa keskeisessä roolissa ovat piirtäjän intressi ja hänen edustamansa maailmankatsomus; Kari Suomalainen oli arvoiltaan konservatiivi (Ylönen 2001, 266; Niiniluoto 1979, 99). Kekkonen edusti hänelle tietyn poliittisen suuntauksen keulakuvaa.

Kuitenkin pilapiirrokset ovat historiantutkimuksen välineenä informatiivinen lähde rekonstruoitaessa aikalaiskäsitysten kautta Kekkosen Suomen syntyä ja kehitystä. Laajan aineiston kautta yksittäiset pilapiirrokset asettuvat osaksi kokonaiskuvaa. Vaikka Karin pilapiirrokset ovat usein reagointeja ajankohtaisiin tapahtumiin, niistä on pidemmällä ajanjaksolla havaittavissa laajempia kehityskulkuja: ne ovat tallentaneet historiaa sen syntyhetkellä. Pilapiirrokset yleensä on myös nähtävä merkittävänä yhteiskunnallisen keskustelun luojana. Pilapiirroksissa on voimaa, ja siksi ne on usein nähty uhkana vallanpitäjille - niin myös Kekkosen ajan Suomessa. Poliittisesti kuohuvina aikoina pilapiirros menestyy, ja sen merkitys kasvaa, kun eri poliittiset suunnat ja arvomaailmat pyrkivät saattamaan kilpailijansa naurettavaan valoon vahvistamalla stereotyyppisiä mielikuvia (Navasky 2013, 35; Rivers 1991, 250-251; Ylönen 2001, 16). Kekkonen ei kyennyt suitsimaan Karia, ja hän ei voinut lopulta muuta kuin niellä "myrkyn" ja kestää Karin terävät pistot (Niiniluoto 1979, 139).

Kari Suomalaisen menestyksen myötä pilapiirtäjät yleistyivät suomalaisissa sanomalehdissä. Kari oli suomalaisen pilapiirtämisen merkittävimpiä kehittäjiä. Hänen vaikutuksensa oli suuri sekä pilapiirroksen merkityksen ja aseman vahvistumisessa että tyylin kehittymisessä. Suomen vaikeasta ja luonnollisesti myös tiedonvälityk-
Katsauksen kuvia on käytetty tieteellisessä tarkoituksessa. 
seen vaikuttavasta ulkopoliittisesta asemasta huolimatta suomalainen pilapiirros kehittyi siihen rooliin ja siihen muotoon, jollaisena me sen nykyään tunnemme. (Yönen 2001, 262-266.)

Karin työssä yhdistyivät hänen kykynsä, poliittinen näkemyksensä ja Helsingin Sanomien tarjoama foorumi, jolla hän pääsi laajalti levittämään mielipiteitään (Porvali 1999, 56-57; Ylönen 2001, 264). Lehti tarjosi Karille taiteellisen vapauden, sillä hän oli omistaja Eljas Erkon suojeluksessa (Porvali 1999, 56-58; Niiniluoto 1990, 18). Kun Kari aloitti Helsingin Sanomissa, hänen kriittinen linjansa ei ollut mitenkään poikkeuksellinen. Hänen kuvansa Kekkosesta oli laajojen kansalaispiirien jakama. Kari itse sanoi olleensa Kekkos-vastaisen rintaman lemmikki. Hän näki Kekkosen 1950-luvulla todellisena vaarana Suomen itsenäisyydelle, ja hänen piirroksistaan välittyy pelko Kekkosen noususta presidentiksi. (Niiniluoto 1979, 138.)

\section{Suomettuminen ja Karin Suomi}

Suomettuminen on ristiriitainen käsite, ja se jakaa suomalaisia historiantutkijoita. Osa korostaa ilmiön vahingollisuutta, ja osa taas kiinnittää huomiota Kekkosen valtakauden saavutuksiin. (Seppänen 2009, 132, 280-283.) Ilmiön taustalla on nähty sotien jälkeinen poliittinen suunnanmuutos ja Neuvostoliitosta riippuvainen ulkopoliittinen asema (Laqueur 1980, 6-7; Vihavainen 1991, 9). Suomettumistermi antoi kasvot ja nimen sille aikakaudelle, jona Neuvostoliitto vaikutti Suomen politiikan taustalla suoraan tai epäsuorasti (Mouritzen 1988, 2, 365, 367).

Vaikka termi syntyikin vasta 1960-luvulla, suomettumisesta voi puhua myös tätä edeltävällä ajalla. Ilmiöön liitetyt piirteet olivat näkyvissä politiikassa ja laajemmin yhteiskunnassa jo aiemmin. (Kallenautio 2005, 305; Vihavainen 1991, 9, 19; Maude 1976, 45; Tarkka 2012, 277-278.) Tämän katsauksen tarkoituksena ei ole ottaa kantaa suomettumiseen itsessään. Tarkoitus on tuoda esiin, miltä Kekkosen vallankäyttö Karin pilapiirroksissa näytti ja miten Kari havainnoi suomettumisilmiötä; millaisia piirteitä hänen näkökulmansa korostaa? Hedelmällisintä onkin keskittyä siihen, kuinka Kari aikalaisena koki suomettumisilmiön. Hänen pilapiirrostensa näkemystä ei pidä ottaa totuutena suomettumisesta vaan yhtenä näkökulmana monista.

Kekkonen ja suomettuminen kietoutuivat syy- ja seuraussuhteeseen. Suomettuminen liittyi Karin pilapiirroksissa vahvasti Kekkosen johtajuuteen ja hänen asemaansa. Kekkonen ei luonut suomettumisilmiötä, mutta piirrosten mukaan se voimistui hänen aikakaudellaan. Myös pilapiirrosten keskeiset suomettumiseen liittyvät elementit ovat vahvasti sidoksissa Kekkoseen. Kari käsitteli Kekkos-aiheisten pilapiirrostensa kautta sitä, miten suomettuminen vaikutti Suomen riippumattomuuteen, porvarilliseen yhteiskuntaan ja demokraattiseen järjestelmään.

Urho Kekkosen valtakaudella kriittisten mielipiteiden esittäminen kuului perustuslain suojaamaan sananvapauteen. Tiedotusvälineisiin kohdistunut paine edisti itsesensuurin voimistumista. Sananvapauden puolustaminen ja käyttäminen oli riippuvainen niistä yksilöistä ja lehdistä, jotka vallitsevasta ilmapiiristä huolimatta hyödynsivät ilmaisuvapauttaan. Karin piirrokset toimivat Kekkos-kriittisenä kanavana vuosikymmeniä. Helsingin Sanomien rooli oli merkittävä antaessaan Karille vapauden säilyttää oman linjansa. Helsingin Sanomien kannalta taas Kari antoi mahdollisuuden tuoda esiin niitä asioita, joista pääkirjoitus ja muu uutissisältö joutuivat vaikenemaan.

Karin pilapiirroksia voi tutkia ikään kuin ulkopuolisen tarkkailijan aikalaiskuvana tai sitten aktiivisen toimijan pyrkimyksenä muokata lukijoiden maailmankuvaa, puuttua kehitykseen ja vaikuttaa harjoitettuun politiikkaan. Sitoutumattoman lehden pilapiirtäjänä Kari Suomalaiselle avautui mahdollisuus muokata laajan yleisön 
käsityksiä. Hän saattoi valtakunnan johtavan sanomalehden kautta tavoittaa nekin, jotka olivat poliittisilta mielipiteiltään eri linjoilla hänen kanssaan. Oman lisänsä hänen suosionsa leviämiseen antoivat hänen säännöllisesti julkaisemansa, suuriin painosmääriin yltävät kokoelmansa. Niiden kautta hän saavutti niidenkin tietoisuuden, jotka eivät kuuluneet Helsingin Sanomien lukijoihin.

Kari Suomalainen nousi myös nimimerkkinsä takaa persoonana esiin tunnetuksi hahmoksi suomalaisessa julkisessa elämässä. Julkisuus lisäsi hänen arvovaltaansa käydä yhteiskunnallista keskustelua. Yksi Karin asemaan vaikuttanut tekijä oli myös se, että hän ei omien sanojensa mukaan ollut puoluepoliittisesti sitoutunut. Näin häntä ei voinut syyttää jonkin poliittisen ryhmän suosimisesta (Niiniluoto 1979, 137-138, 141), vaan hänellä oli mahdollisuus kritisoida kaikkia. Hän halusi pysyä syrjässä politiikan ja poliitikkojen suhteen säilyttääkseen abstraktin näkökulmansa ja käsitelläkseen pilapiirroksissaan poliittisia toimijoita ainoastaan heidän toimintansa kautta (Niiniluoto 1977, 134-135). Tähän perustui varmastikin Karin pyrkimys pitää henkilökohtaisella tasolla etäisyyttä Kekkoseen (Niiniluoto 1979, 140).

Oman riippumattomuutensa vuoksi Karista tuli pelätty, jopa vihattu hahmo, jota kohtaan kanavoitui voimakasta arvostelua ideologisesti eri mieltä olevien taholta. Karin voima oli suuresti juuri siinä, että hän ei pelännyt asettua vastakkain kenenkään poliittisen tai yhteiskunnallisen toimijan kanssa, jonka arvomaailma soti hänen omaansa vastaan. Kaikki poliitikot oikealla ja vasemmalla saivat olla varpaillaan hänen pilapiirrostensa suhteen. Tosin Kari nautti myös poliittisissa piireissä kunnioitusta, sillä mielipide-eroista huolimatta hänen pilapiirrostensa osuvuutta ja tarkkanäköisyyttä harva saattoi vähätellä.

Loppujen lopuksi pääsy hahmoksi Karin pilapiirrokseen koettiin saavutuksena. Pilapiirroksessa huumori pehmentää muuten voimakasta viestiä. Kekkosenkin tiedetään raivostuneen Karille ja halunneen suitsia häntä, mutta toisaalta tiedetään hänen arvostaneen Karin pilapiirroksia. Hänen piirroksensa naurattivat lopulta siis myös kritiikin kohteita. Karin voi nähdä vaikeina kylmän sodan vuosina lievittäneen jännitteitä antaessaan kansalaisten suuttumukselle turvallisen purkautumisväylän.

Karin pilapiirrosten myötä Helsingin Sanomat saattoi esittää vallitsevasta Kekkosja neuvostomyönteisestä suuntauksesta poikkeavia käsityksiä. Karin pilapiirrosten kautta Kekkos-kriittinen näkemys tunkeutui Helsingin Sanomissa esille itsesensuurin läpitunkemasta media-ilmapiiristä huolimatta. Pilapiirrokset - ja varsinkin Karin pilapiirrokset - on nähtävä sananvapautta puolustavana vaihtoehtoisena mielipidekanavana tuoda esiin niitä asioita, joista lehdet joutuivat muuten vaikenemaan. Karin pilapiirroksia ei pidä ajatella objektiivisena totuutena, vaan ne on nähtävä yhtenä maailmankatsomuksena ja näkökulmana. Tämän katsauksen piirrosten kautta avautuukin kuva Karin Suomesta.

Sotienjälkeinen aika asetti haasteita suomalaiselle journalistiselle työlle. Tiedotusvälineissä jouduttiin ottamaan huomioon uudet ulkopoliittiset realiteetit. Karin piirrokset ja Helsingin Sanomat on nähtävä osana tätä muuttunutta mediaympäristöä. "Vaaran vuosina" 1944-1948 tiedotusvälineitä ohjattiin valtiojohdon taholta varovaisuuteen Neuvostoliiton suhteen. Itsesensuurin siemen oli kylvetty. (Salminen 2004, 190-191.) Tiedonvälityksestä kehittyi varsinainen taistelukenttä osana laajempaa vastakkainasettelua kilpailevien maailmankatsomusten välillä.

Vasemmiston piirissä pyrittiin aktiivisesti valjastamaan kaikki tiedotustoiminta oman asian puolelle siirrettäessä Suomi sosialismiin. Vastapuolellakin ymmärrettiin tiedotusvälineiden rooli puolustettaessa vallitsevaa yhteiskuntajärjestelmää. Marxilaisen ja liberaalia läntistä journalistista näkemystä edustavan suuntauksen välillä alkoi taistelu informaation hallinnasta. (Salminen 2004, 21,23.) Politisoituvassa viestinnässä merkittävään rooliin nousivat sitoutumattomat sanomalehdet. Itsesensuurin ja Kekkosen varaan rakentuneen konsensuksen myötä Yle ja puoluelehdistö joutuivat 
omaksumaan entistä tiukemmin roolin vasemmistolaisen ja neuvostoliittolaisen tiedotuspropagandan välineenä. (Salminen 2004, 23, 24, 26, 28-29, 146, 159, 187-189.)

Helsingin Sanomat ui vastavirtaan ja taisteli sitoutumattoman lehdistön aseman säilyttämiseksi läntisen journalistisen perinteen puolesta marxilaista vaikutusta vastaan. Karin pilapiirrokset olivat keskiössä jakaantuneessa mediakentässä; hän edusti kaikkea sitä, mitä voimistuva marxilainen koulukunta vastusti - itsenäistä, sitoutumatonta ja yksilökeskeistä tiedonvälitystä. (Salminen 2004, 78-79, 173-174.) Katsaukseen valitut esimerkkipiirrokset antavat kattavan läpileikkauksen siitä, millaisena Kekkosen vallankäyttö näyttäytyi Karin katsantokannassa ja millaista Kekkos-kuvaa hän rakensi yhtenä suomalaisen median harvoista kriittisistä äänistä. Esiin nousevat ulkopoliittinen linja, puolueettomuuspolitiikka, ulkopoliittinen diskriminointi, yhteiskunnallinen ilmapiiri ja demokratian tila.

\section{Kekkosen ulkopolitiikka ja Karin linja}

Kari arvosteli avoimesti piirroksissaan Neuvostoliiton puuttumista Suomen sisäisiin asioihin. Hänen pilapiirroksensa edustivat vastavoimaa puolustaessaan kansallista etua ulkopolitiikassa. "Toiset pitivät Paasikiven reaalipolitiikkaa myöntyväisyyden rajana, ja toiset katsoivat Mannerheimin pidättyvyyden olleen oikea linja. Kekkosen kannattajat näkivät hänen toimiensa pysyvän isänmaallisuuden rajoissa". (Häikiö 2008, 198-199.)

Suomen ja Neuvostoliiton suhteiden rauhallinen jakso päättyi 1950-luvun lopulla, kun kommunistien vaalivoitto vuoden 1958 vaaleissa muutti sisäpoliittista asetelmaa (Suomi 1992, 130, 132). Maiden välit viilenivät, ja niiden suhteissa alkoi yöpakkasiksi nimitetty kriisi. Neuvostoliitto painosti Suomea kaataakseen hallituksen. (Rentola 1997, 414.) Kekkonen lähti vuoden 1959 alussa epäviralliselle lomamatkalle Leningradiin tutustuakseen kulttuuriin. Neuvostoliiton painostus Suomea kohtaan päättyi Kekkosen ja neuvostojohdon tapaamiseen "sattumalta". (Suomi 1992, 201; Kallenautio 2005, 98.)

Kari otti piirroksellaan (Helsingin Sanomat 23.1.1959) kantaa yöpakkaskriisiin. Piirroksesta näkee Karin tuon ajan erittäin voimakkaan Kekkos-vastaisuuden. Hän katsoo kriisin olleen ennalta lavastettu Kekkosen aseman vahvistamiseksi, eikä mitään todellista kriisiä ollut olemassakaan. Kari kuvaa Kekkosen kulttuurimatkan "Potemkinin kulisseina" (Seppänen 2004, 176-177). Kuvassa silmää iskevä Hruštšov viittaa Kekkosen ja Neuvostoliiton yhteistyöhön Fagerholmin hallituksen kaatamiseksi. Yöpakkasten seurauksena alettiin yleisesti puhua ulkopoliittisista "edellytyksistä", ja Kari arvosteli kriisin hyödyntämistä sisäpolitiikassa. Neuvostoliitolla oli valtaa Suomen hallitusratkaisuihin, ja sisäpolitiikassa menestyivät sen tukemat henkilöt (Suomi 1992, 211; Seppinen 2004, 334).

Kekkonen lähti syksyllä 1961 Yhdysvaltoihin, jonne hän sai Suomesta tiedon Neuvostoliiton lähettämästä nootista (Suomi 1992, 446-448; Kallenautio 2005, 136). Toisessa Karin piirroksessa (Helsingin Sanomat 3.11.1961) Kekkosta odotetaan kuin pelastavaa sankaria, ja hän palaa kotiin huolettomana kriisistä huolimatta. Kari vihjaa nootin liittyvän vaaleihin. Maalaisliitto lupaa piirroksessa Kekkosen järjestävän asiat kuntoon. Kari katsookin maalaisliiton pelaavan noottikriisillä presidenttipeliä. Noottikriisi hyödytti Kekkosta, ja hänestä tuli erottamaton osa sisä- ja ulkopolitiikkaa (Soikkanen 2003, 43-44; Suomi 1992, 545,548; Seppinen 2004, 401). Kari kuvaa piirroksessa Suomessa vallinnutta epävarmuutta. Siitä näkee hänen suhtautumisensa kriisin vakavuuteen: hän antaa kuvan, että se oli vaarattomampi, kuin on annettu ymmärtää. 


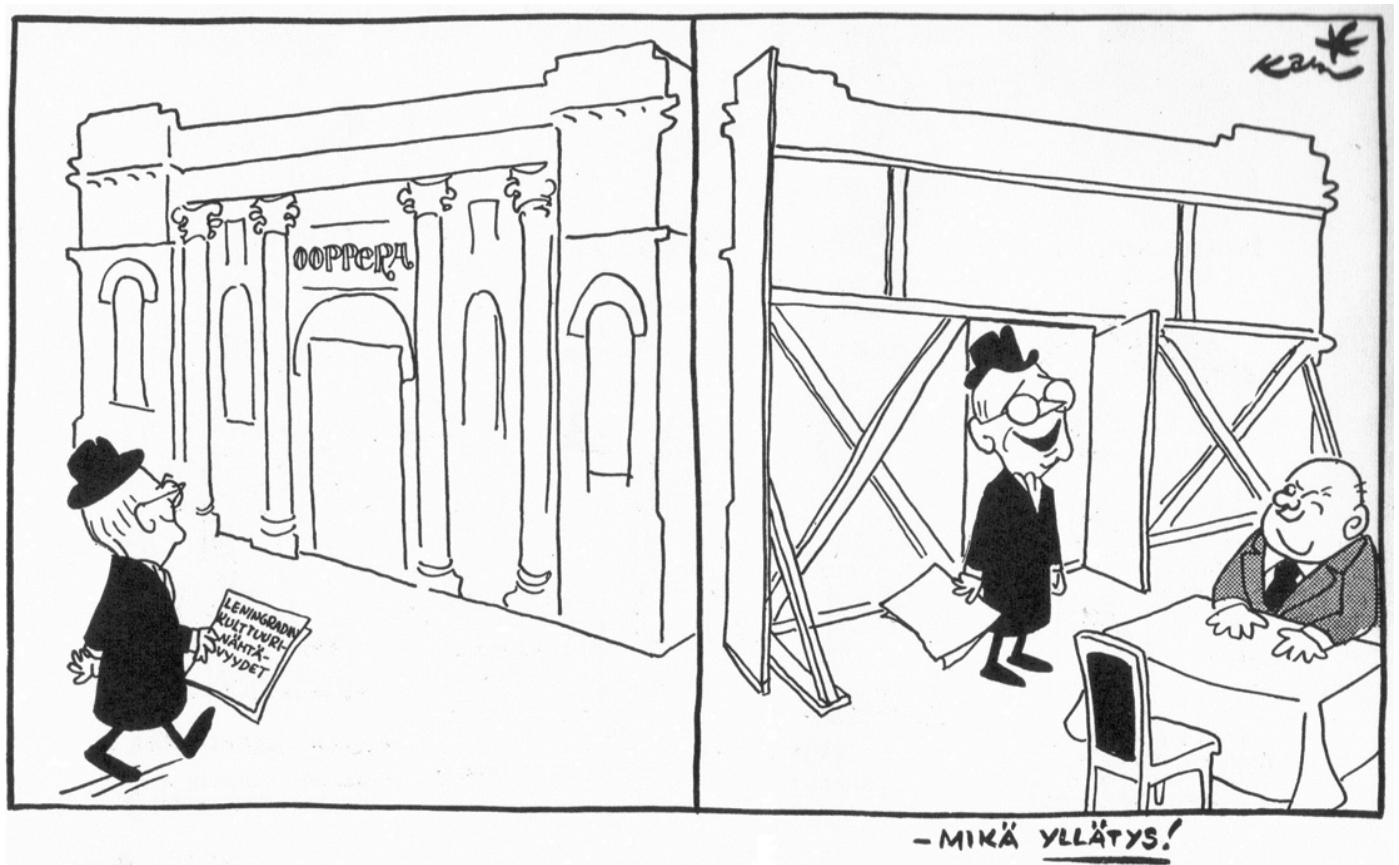

HS. 23. I. 59

Kulttuurin neuvottelupäivät

Kari otti piirroksillaan kantaa yöpakkaskriisiin ja viittasi sen olleen lavastettu. Kuva: HS 23.1.1959.

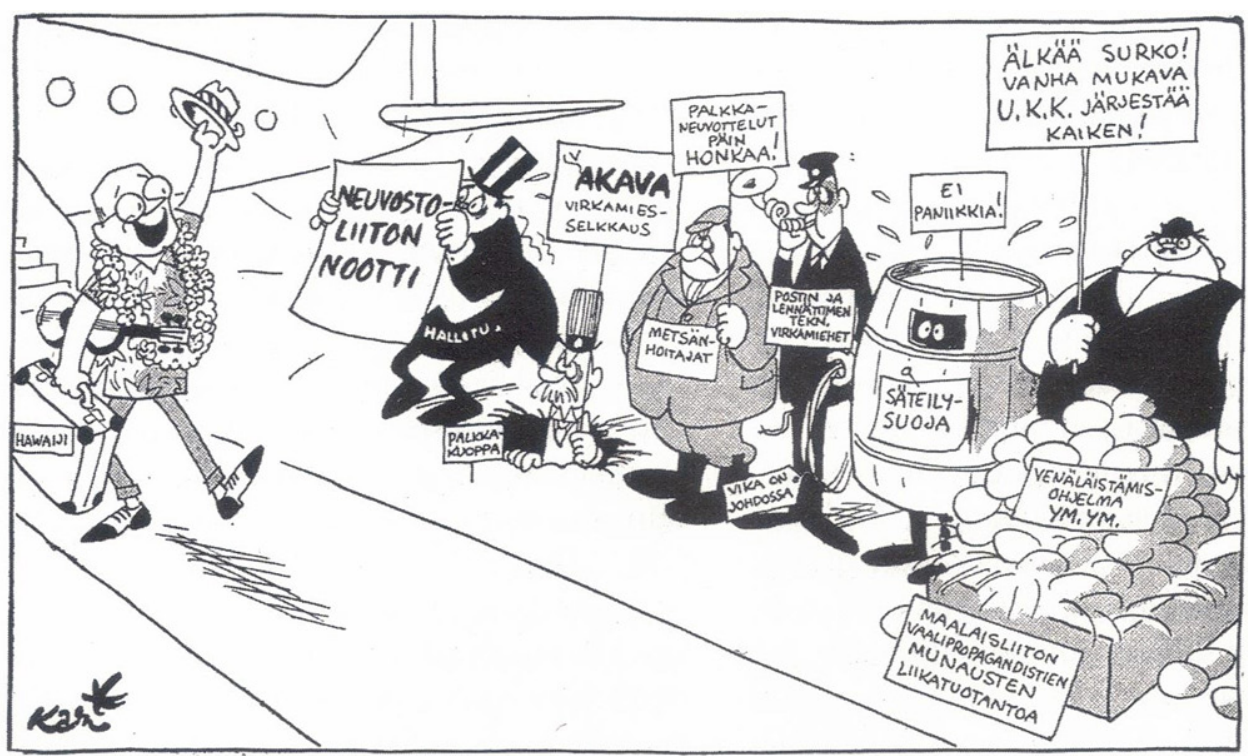

- Aloha! Onko tapahtunut mitään erikoista sillä aikaa kun olin poissa? HS 3.11.1961

Karin pilapiirros, jossa Kekkonen palaa noottikriisistä huolimatta huolettomana Yhdysvalloista Suomeen, vihjaa maalaisliiton pelanneen noottikriisillä presidenttipeliä. Kuva: HS 3.11.1961. 
Tšekkoslovakian miehitys syksyllä 1968 oli vaikeaa aikaa Suomelle ja Kekkoselle henkilökohtaisesti. Kekkonen oli uskonut, että Neuvostoliitto antaa liittolaistensa kehittyä ilman sotilaallista puuttumista asioihin, mutta miehitys sai Suomen pelkäämään samaa kohtaloa tai ainakin tiiviimpää yhteistyötä Neuvostoliiton kanssa. Tšekkoslovakian tapahtumat olivat yllätys Suomen johdolle. (Suomi 2010, 441, 443-444; Meinander 1999, 411-412; Kallenautio 2005, 214, 216.)

Eräs Karin asiaa käsittelevä piirros (Helsingin Sanomat 11.10.1968) liittyy Neuvostoliiton pääministeri Aleksei Kosyginin Suomenvierailuun myöhemmin syksyllä. Suomessa oltiin huolissaan matkan tavoitteesta. (Suomi 2010, 444-445; Meinander 1999, 412; Jacobson 2001, 462.) Piirros kuvaa hyvin Suomessa laajasti vallinnutta epävarmuutta, joka ulottui Kekkoseen saakka. Nyt Kari ei piirroksessaan epäile matkan olevan Suomen sisäpolitiikkaan liittyvää ulkopoliittista peliä, eikä hän arvostele Kekkosta. Piirroksen Kekkonen näyttää olevan aidosti huolissaan Suomen asemasta. Piirros tiivistää hyvin Tšekkoslovakian kriisin vaikutuksen Suomeen: epävarmuuden jälkeen tuli suuri helpotus. Tässä piirroksessa Kari esittää Kekkosen sympaattisessa valossa. Vaikka Kari pysyi Kekkosen kriitikkona, alkoi hän kuitenkin nähdä tämän lempeämmin.

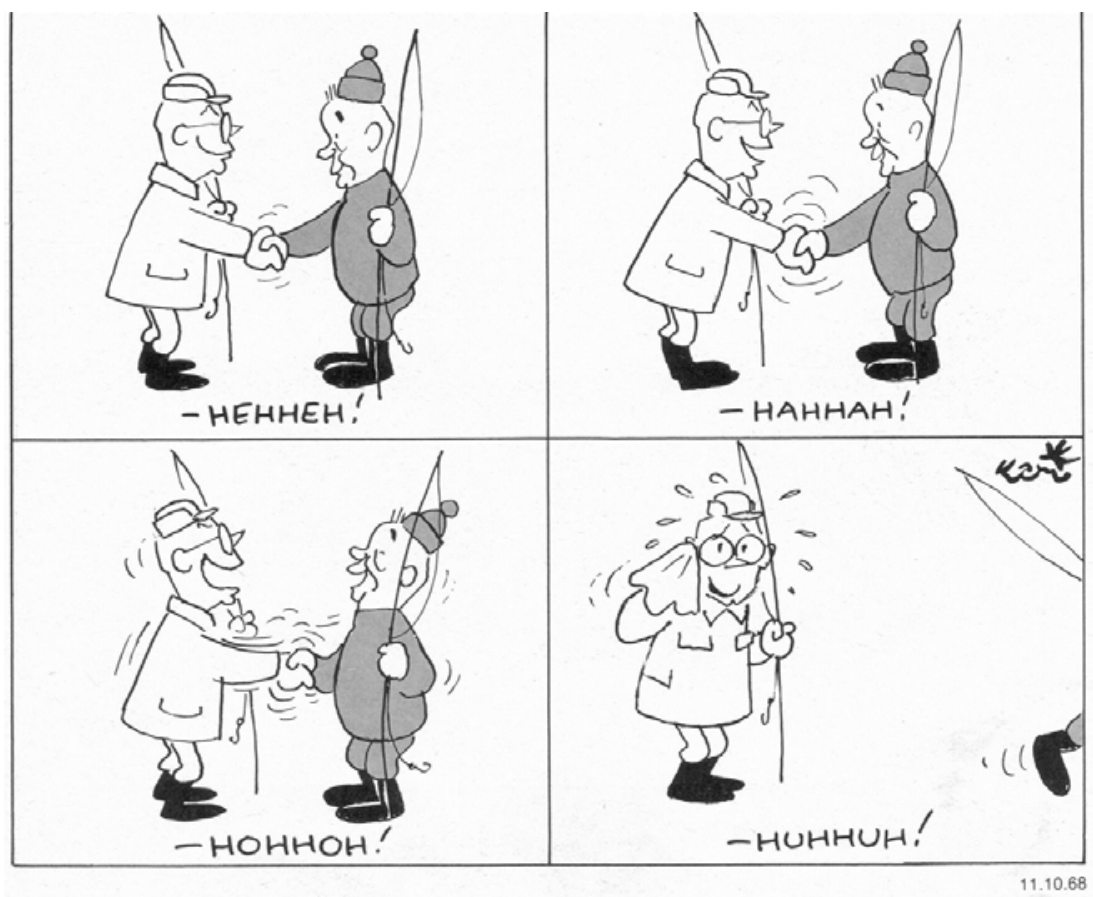

Neuvostoliiton pääministeri Aleksei Kosyginin Suomenvierailua kuvaava pilapiirros osoittaa, että Tšekkoslovakian kriisi sai Karin näkemään Kekkosen aiempaa lempeämmin. Kuva: HS 11.10.1968.

\section{Puolueettomuuden ihanne ja todellisuus}

Kari toivoi Paasikiven periaatteiden kunnioittamista Kekkosen aikakaudellakin, ja hän laittoi piirroksissa usein vastakkain Paasikiven reaalipolitiikan ja Kekkosen liiallisen myötäilyn politiikan (Vihavainen 1991,33). Piirrokset henkivät epäluottamusta Kekkosen aikaa kohtaan ja pelkoa etääntymisestä Paasikiven alkuperäisistä tavoitteista. Kari toi esiin eron puolueettomuuden ihanteen ja Suomen puolueettomuuspolitiikan todellisuuden välillä. Hänen piirroksensa varoittivat puolueettomuuteen 


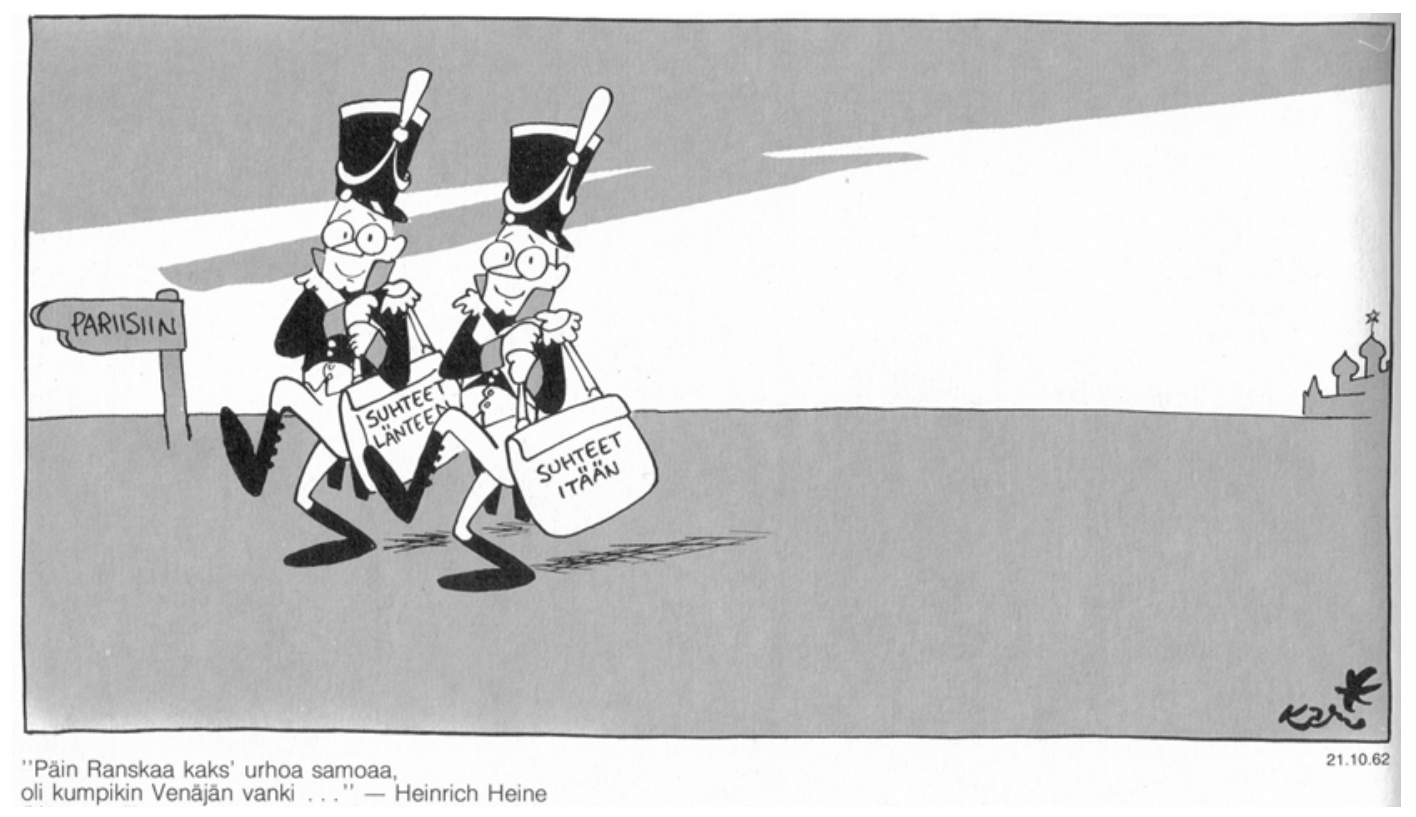

Kekkosen valtiovierailua Ranskaan kuvaava piirros mukailee Heinrich Heinen runoa Napoleonin Venäjän-retkestä. Kuva: HS 21.10.1962.

kohdistuvista vaaroista. Vallitsevan tilanteen kuvaamisen ohella piirrokset tuovat esille myös näkemyksen siitä, millainen suomalaisen yhteiskunnan tulisi olla. Pilapiirtäjä ei voi ainoastaan seurata poliittista tilannetta, vaan hänen on tuotava esiin oma mielipiteensä hyvästä yhteiskunnasta.

Suomen suhteet länteen olivat riippuvaisia niiden vaikutuksesta idänsuhteisiin. Yksi Karin piirros (Helsingin Sanomat 21.10.1962) liittyykin Kekkosen valtiovierailuun Ranskaan, sen jälkeen kun tämä oli juuri palannut Neuvostoliiton matkalta (Suomalainen 1985, 130). Piirroksessa viitataan Neuvostoliiton erityisasemaan, kun kaksi Kekkosta matkaa Ranskaa kohti mukaillen Heinrich Heinen runoa Napoleonin Venäjänretkestä. Se kertoo Suomen voivan rakentaa suhteita länteen vain, jos ne eivät ole ristiriidassa hyvien idänsuhteiden kanssa.

Kari ei piirrostensa suomettumiskritiikistä huolimatta menettänyt uskoaan Suomen kansalliseen selviytymiseen. Hän ymmärsi kuitenkin idealismin ja realismin välimatkan ja totesi eräässä piirroksessaan, ettei moraalista ole jäljellä kuin moraalisten miesten patsaat. Hän ei maininnut suomettumistermiä monessakaan piirroksessaan, vaikka suomettuminen sinänsä oli keskeisessä osassa hänen tuotantoaan. Suomettumisen takana olevat tekijät esiintyivät piirroksissa laaja-alaisesti jo kauan ennen termin syntyä. Hän olikin ensimmäisiä, joka nosti esiin myöhemmin suomettumisena tunnetun ilmiön.

Karin piirrokset kuvaavat idän ja lännen vastakkainasettelun heijastumista Suomeen. Hän halusi piirrostensa kautta osoittaa puolueettomuuspolitiikan käytännön ongelmat. Kekkonen sai maailmalla kunnioitusta taitavasta henkilökohtaisesta suhteiden hoidostaan (Soikkanen 2003, 49, 52-53), eikä Karikaan piirroksissaan arvostellut Kekkosen kykyjä. Piirroksista välittyy kuitenkin kritiikki Kekkosen keskittymisestä henkilökohtaisessa diplomatiassa liiaksi itään. Ulkomailla Suomen Neuvostoliittoa myötäilevä toiminta vahvisti kuvaa suomettumisesta, vaikka Urho Kekkonen pyrkikin hälventämään maailmalla epävarmuutta Suomen puolueettomuudesta ja tuomitsemaan puheet suomettumisesta (Suomi 2010, 457-458, 486-488, 490; Kallenautio 2005, 173-174). 
Kari kuvasi piirroksissaan myös sitä, miten hyvien suhteiden säilyttäminen Neuvostoliittoon oli Suomen diplomatian keskeisin tavoite. Suomi ei voinut arvostella neuvostoleirin ihmisoikeusloukkauksia niin kuin muut länsimaat. Suomen johto vaikeni Itä-Euroopan tilanteesta, kuten eräs Karin piirroksista havainnollistaa (Helsingin Sanomat 12.11.1980). Kuvassa Kekkonen on lähdössä Moskovaan. Kuva liittyy Puolassa alkaneisiin demokratiamielenosoituksiin Solidaarisuus-liikkeen johdolla (Visuri 2006, 245; Reimaa 2013, 222). Puolan tilanne asetti vastakkain sosialistisen leirin todellisuuden ja ETYK:n tavoitteet.

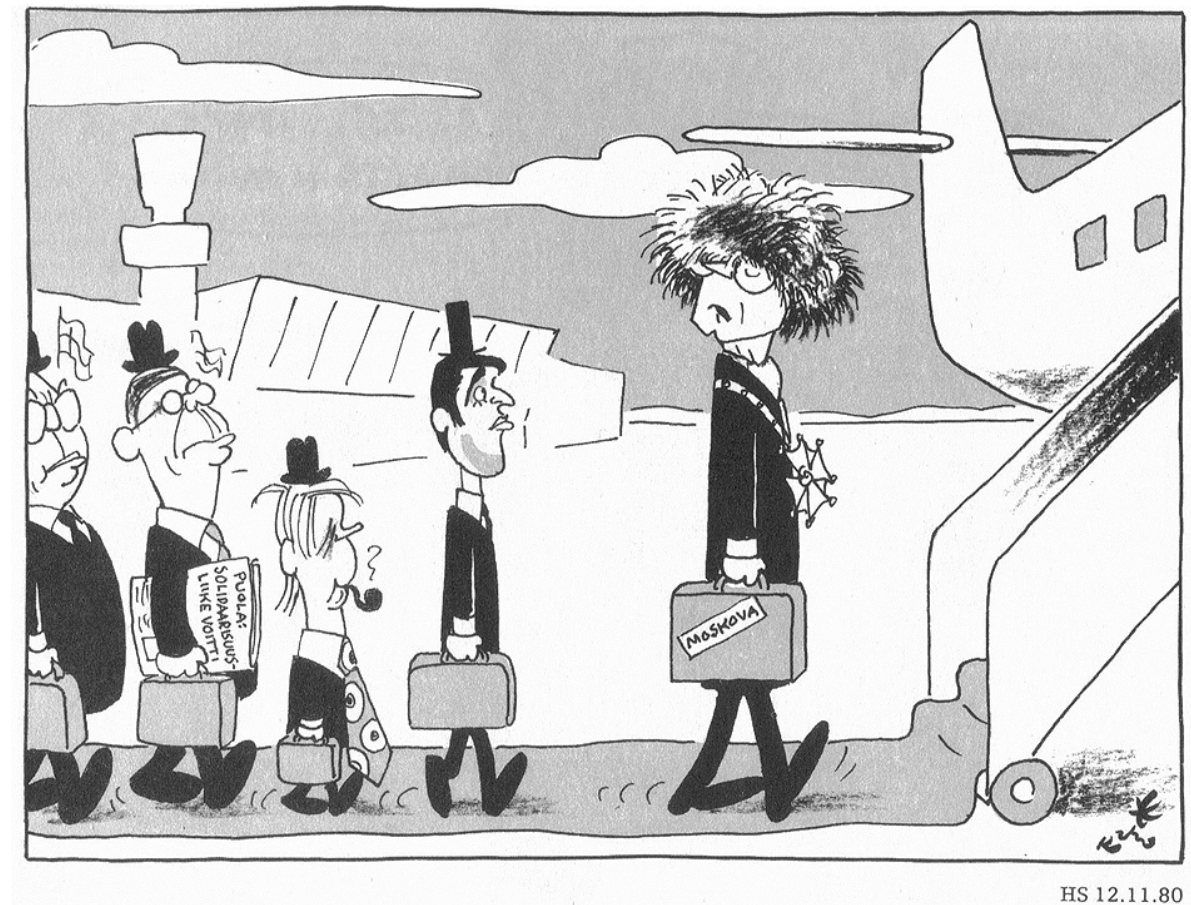

- Muistakaa, että sitten kun kerromme tukevamme yhteisiä ETYK-pyrkimyksiä, emme käytä sanaa solidaarisuus.

Karin pilapiirrokset kertoivat hyvien Neuvostoliiton suhteiden olleen Suomen diplomatian keskeisin tavoite. Kuva: HS 12.11.1980.

\section{Ulkopoliittinen diskriminointi ja Kekkos-konsensus}

Kari käsitteli piirroksissaan laajasti ulkopoliittisen diskriminoinnin seurauksia sisäpolitiikassa. Yöpakkaskriisi toi ulkopolitiikan vastakkainasettelun kärjistetymmin esiin, sillä se voimisti Kekkosen arvostelua (Suomi 1992, 214-215; Kallenautio 2005, 104). Suomen politiikassa oli kaksi kilpailevaa suuntausta: Kekkos-vastainen ja Kekkosta tukeva rintama. Piirroksissaan Kari kuvaa voimakkaasti jakautuneen sisäpoliittisen asetelman, ja niissä korostuu SDP:n johtava rooli Kekkosen vastaisessa taistelussa. Oppositio rakensi yhteisrintaman Kekkosta vastaan. Kekkonen oli saamassa varteenotettavan kilpailijan myös 1962 vaaleihin, kun SDP asetti Olavi Hongan presidenttiehdokkaakseen. Puolue keskittyi yöpakkasten jälkeen Kekkosen kaatamiseen seuraavissa vaaleissa. (Soikkanen 2003, 44; Suomi 1992, 2015; Kallenautio 2005, 103.) Syntyi Honka-liitto. 


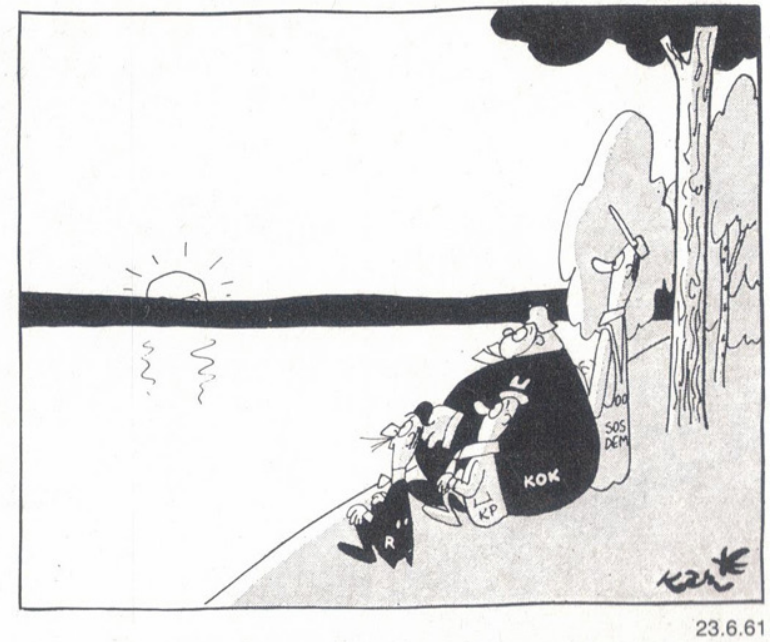

Pilapiirros ennakoi vuoden 1962 presidentinvaalien tulosta: aurinko ei laske juhannuksena, eikä Kekkonen poistu vallasta. Kuva: HS 23.6.1961.

Neuvostoliiton edustajat seurasivat tarkkaan Suomen sisäpoliittista kehitystä ja alkoivat entistä enemmän puuttua siihen virallisesta puuttumattomuuden korostamisesta huolimatta (Nevakivi 1996, 157-158). Kekkonen aikoi pysyä Karin pilapiirroksen (Helsingin Sanomat 23.6.1961) mukaan vallassa. Piirros on tyypillistä Karia ja perustuu yksinkertaiseen vähäsanaiseen oivallukseen kuvaten hyvin presidentinvaalijännitteitä. Piirroksessa oppositio seuraa keskikesällä vakavana, kun aurinko ei laskekaan; Karin pilapiirros ennakoi oikein, että Kekkonen ei poistu maisemista. Lyhyt kuvateksti paljastaa piirroksen ratkaisun, sillä eihän aurinko juhannuksena laske. Piirros huokuu pahaenteistä uhkaa Honka-liiton suhteen ja antaa ymmärtää, että Kekkosella on vielä sanansa sanottavana.

Karin piirrosten hahmot kuvasivat hyvin puolueiden ominaisluonnetta Kekkosen kaudella. Puolueet ovat piirroksissa keskeisessä roolissa Kekkosen valta-aseman taustalla. Hahmot muistetaan edelleen, vaikka puolueet ovatkin muuttuneet entisajoista. 1960-luvulla ne vakiintuivat piirroksissa kuvaamaan suomalaista puoluepolitiikkaa (Ylönen 2001, 269). Poliitikot vaihtuivat, mutta puoluehahmot pysyivät mukana. Ne näyttivät puolueiden taistelun kovuuden ja raadollisuuden mutta myös sen koomisuuden ja naurettavuuden.

SDP oli keskeisessä osassa Karin ulkopoliittista diskriminointia käsittelevissä piirroksissa. Sen ja maalaisliiton vastakkainasettelu näkyy selkeästi piirroksista. Kokoomusta Kari käsitteli usein pitäen esillä ulkopoliittisen diskriminoinnin jatkumista. Kokoomuksen asema symboloi piirroksissa suomettumisen aiheuttamaa uhkaa porvarilliselle yhteiskunnalle oikeistovastaisuuden kasvaessa. Piirroksissa korostuu kokoomuksen ja Kekkosen keskinäinen suhde. Kari kuvaa puoluepolitiikan voimakasta vastakkainasettelua Kekkosen kauden alkupuolella.

Puolueiden ulkopoliittisen konsensuksen aika alkoi uudesta kansanrintaman luomisesta, ja niiden asemat vakiintuivat SDP:n ryhmityttyä Paasikiven-Kekkosen linjalle. Kekkosen keskeinen tavoite saada SDP ulkopolitiikkansa taakse toteutui (Soikkanen 2003, 44). Kekkosen ulkopolitiikkaan perustuva johtajuus heijastui sisäpolitiikkaan, ja puolueet mukautuivat hänen ohjausvaltansa alle (Soikkanen 2003, 57-58).

Eräs Karin piirroksista (Helsingin Sanomat 27.5.1975) kuvaakin hyvin, miten puolueista tuli Kekkosen "itsevaltiuden" myötäilijöitä, ja ne alkoivat esiintyä Kekkosen 
nimissä ja nimessä. Piirros liittyy poikkeuslakiin ja sen jälkeiseen aikaan. Puolueiden toiminnassa oli pelkoa diskriminoinnista, suomettumisen kulttuurin tuomaa mielistelyä ja uskoa Kekkosen kaikkivoipaisuuteen. Kari arvostelee puolueita kansanvallan unohtamisesta. Piirroksessa voi nähdä symboliikkaa yhteiskunnallisesta kehityksen suunnasta. Kari haluaa nostaa esille SDP:n linjanmuutoksen ja johtavan roolin 1970-luvulla (Suomi 2010, 576, 579; Meinander 1999, 439). Karin piirroksista voi tehdä tulkinnan, että heikot puolueet loivat vahvan presidentin ulkopoliittisen konsensuksen hengessä.

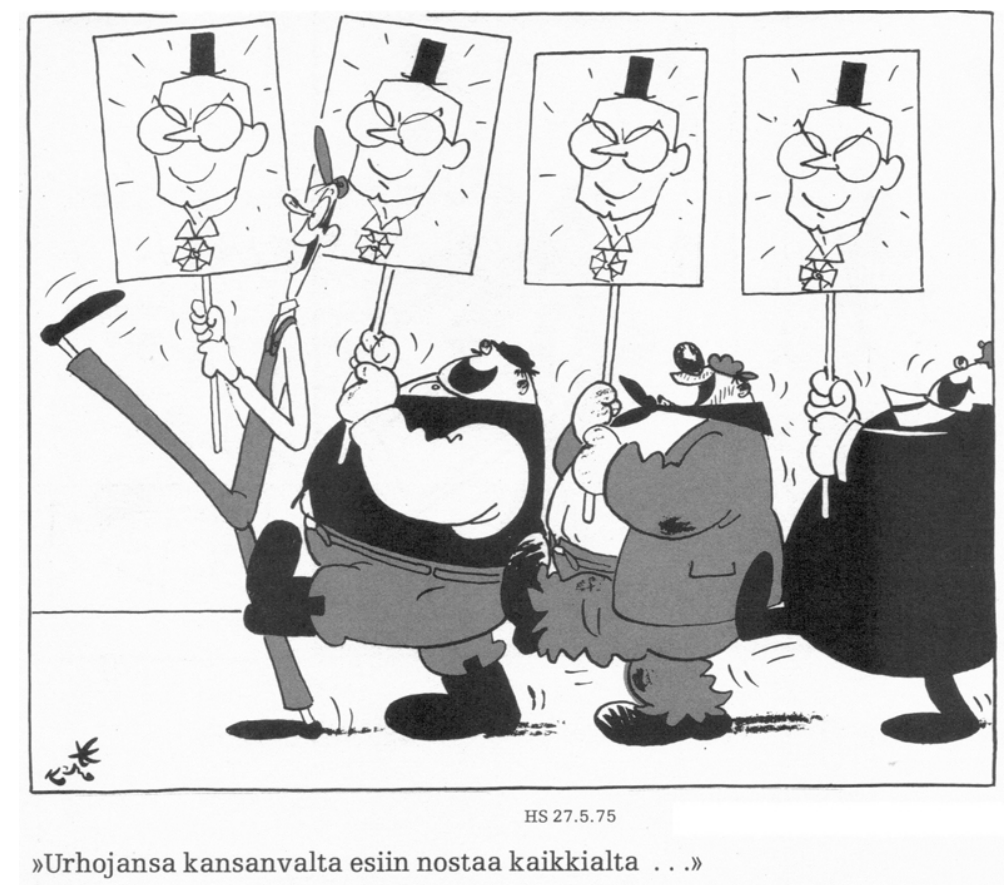

Puolueista tuli 1970-luvulla Kekkosen "itsevaltiuden" myötäilijöitä. Kuva: HS 27.5.1975.

\section{Yhteiskunnallinen virtaus vie vasemmalle}

Kari oli huolissaan Kekkosen vallan vaikutuksista yhteiskunnalliselle ilmapiirille. Kylmän sodan aikana isänmaallisuus ei näkynyt avoimesti yhteiskunnassa, sillä suomalaiset eivät saaneet olla avoimesti ylpeitä kulttuuristaan ja historiastaan (Vihavainen 1991, 208). Historiakäsitykseen tuli piirteitä neuvostoliittolaisesta tulkinnasta, joka vaikutti nuorten tietoisuuteen (Vihavainen 1991, 186; Meinander 1999, 394). Eräässä piirroksessaan (Helsingin Sanomat 6.5.1960) Kari kritisoikin itsenäisyyden hyssyttelyä Neuvostoliiton pelossa.

Piirros liittyy Kekkosen puheeseen soveliaasta käytöksestä: "On elettävä sävyisästi, eikä käytävä itsenäisyydellä elämöimään" (Suomalainen 1985, 112). Kari korostaa piirroksessa suomalaisten oikeutta olla ylpeitä isänmaasta, itsenäisyydestä ja vapaudesta. Hän vertaa piirroksessa hiljaista isänmaan kunnioittamista ja suomettunutta ulkopolitiikalla ilakoimista osoittaakseen kumpi toiminta vaarantaa Suomen itsenäisyyden ja aseman. Hän tuomitsee Kekkosen syytöksen itsenäisyydellä elämöimisestä ja katsoo ulkopoliittisen diskriminoinnin olevan epäitsenäisyydellä elämöintiä. Piirroksen henki on, että itsenäisyyttä voi kunnioittaa hiljaisuudella muttei vaikenemisella. 


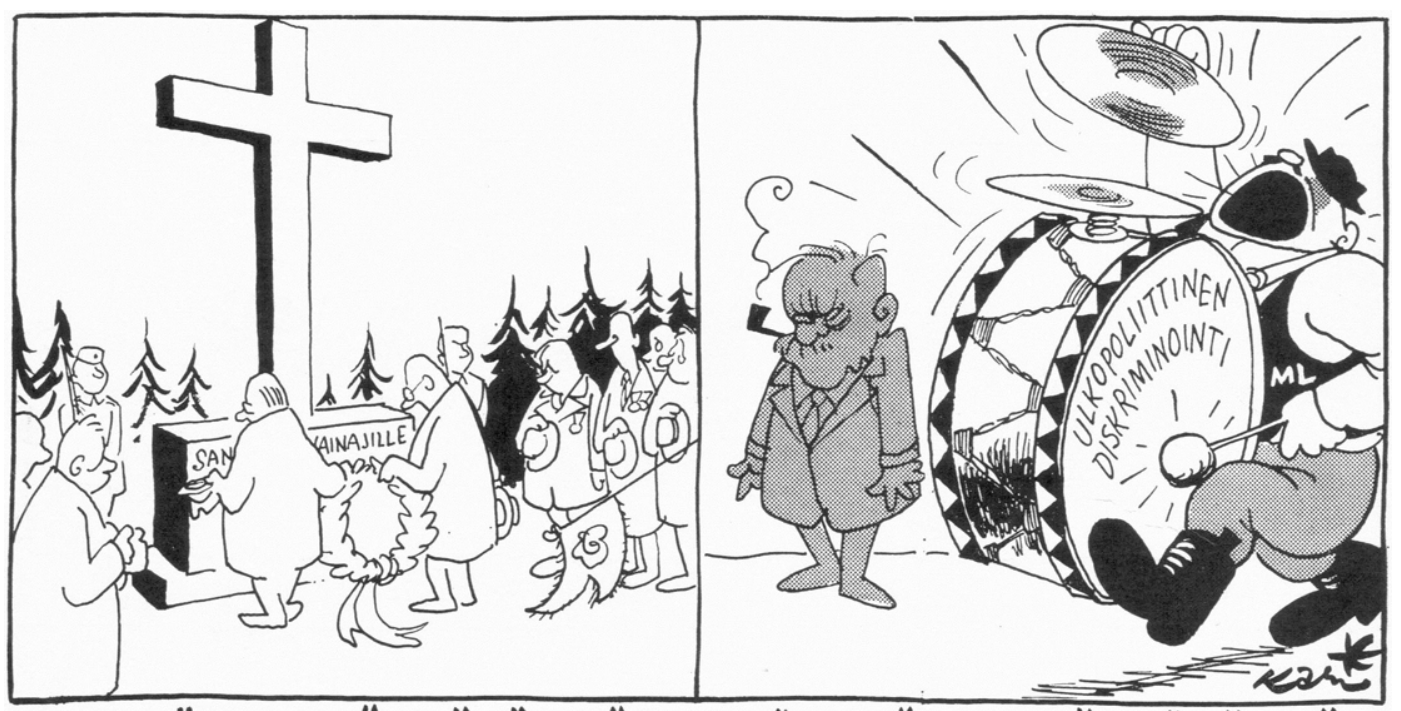

"ITSENÄISYYDELL"̈ ELÄMÖINTIM" EPÄITSENÄISYYDELL"Ä ELÄMÖINTIM̈

HS. 6. 5,60

Melua ja hiljaisuutta

Karin pilapiirros kritisoi itsenäisyyden hyssyttelyä Neuvostoliiton pelossa. Kuva: HS 6.5. 1960.

Itsesensuuri oli yksi suomettumisen keskeisimpiä ilmenemismuotoja, sillä se ruokki suomettumista edelleen vaikuttamalla kansalliseen identiteettiin. Itsesensuurin myötä Suomen ulkopolitiikasta ja Neuvostoliitosta ei sallittu käytävän normaaliin länsimaiseen journalismiin kuuluvaa keskustelua. Kari arvosteli piirroksissaan tiedotusvälineitä journalistisen perinteen unohtamisesta. Niissä tiedotusvälineet olivat suomettuneen propagandan palveluksessa.

Yksi Karin kiinnostavimmista piirroksista (Helsingin Sanomat 27.1.1959) liittyykin Kekkosen lausuntoon, jossa hän tuomitsi suomalaiset piirtäjät ja pakinoitsijat, jotka olivat suututtaneet Neuvostoliiton. Tarkemmin sanottuna suuttumuksen kohteena oli Karin "Volgan lautturit" -piirros. Piirros osallistui kansainväliseen pilapiirroskilpailuun, ja se sai maailmanlaajuista huomiota nousten aiheeksi myös Suomen ja Neuvostoliiton diplomatiassa. Kekkonen sanoi radiossa Leningradista palattuaan toivovansa, että Neuvostoliitto suhtautuu meidän pakinoitsijoihimme ja piirtäjiimme, kuten Fredrik Suuri:" Älkää välittäkö, eivät ne graniittia pysty murtamaan". (Suomi 2010, 275; Niiniluoto 1977, 142; Porvali 1999, 82; Suomalainen 1985, 96.)

Yleisesti tiedettiin arvostelun olevan oikeasti suunnattu ainoastaan Karia kohtaan. Kari itse otti Kekkosen hyökkäyksen vastaan "kohteliaisuutena" pilapiirtäjälle. Hän vastasi tietenkin uudella piirroksella Kekkosen kommenttiin. Piirroksessa Kekkonen valvoo isoveljenä Karia tämän työskennellessä. Kari ei muuttanut linjaansa painostuksen alla.

Poliittinen kulttuuri muuttui vähitellen Kekkosen valtakaudella avoimen neuvostomyönteiseksi. Vasemmistolaiset ihailivat neuvostojärjestelmän utopiaa, ja porvarillisetkin tahot joutuivat sen myötäjuoksijoiksi. Monet halusivat edistää urakehitystään politiikassa ja yhteiskunnassa pyrkimällä saamaan luotettavan maineen neuvostoliittolaisten silmissä. (Vihavainen 1991, 25.) Kari muistuttaa piirroksissaan Suomen kärsineen epäoikeudenmukaisuudesta Neuvostoliiton taholta. Piirrokset arvostelevat poliittista kulttuuria, joka unohti historialliset kokemukset. Hän näki YYA-aikanakin sen vanhassa valossa edelleen vihamielisenä valtana. 


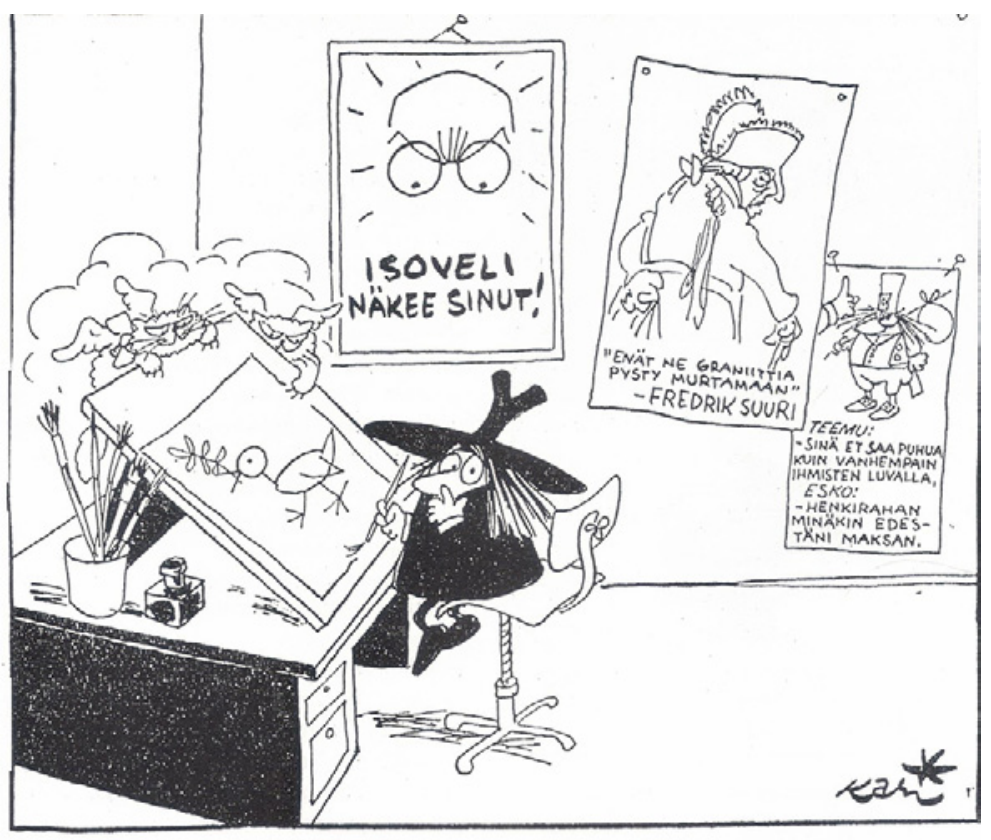

- Ketăhăn kumman piirtäiää presidentti puheessaan mahtoi tarkoittaa? HS 27.1.1959
Kari vastasi piirroksella Kekkosen puheeseen, jossa tämä tuomitsi suomalaiset piirtäjät ja pakinoitsijat. Kuva: HS 27.1.1959.

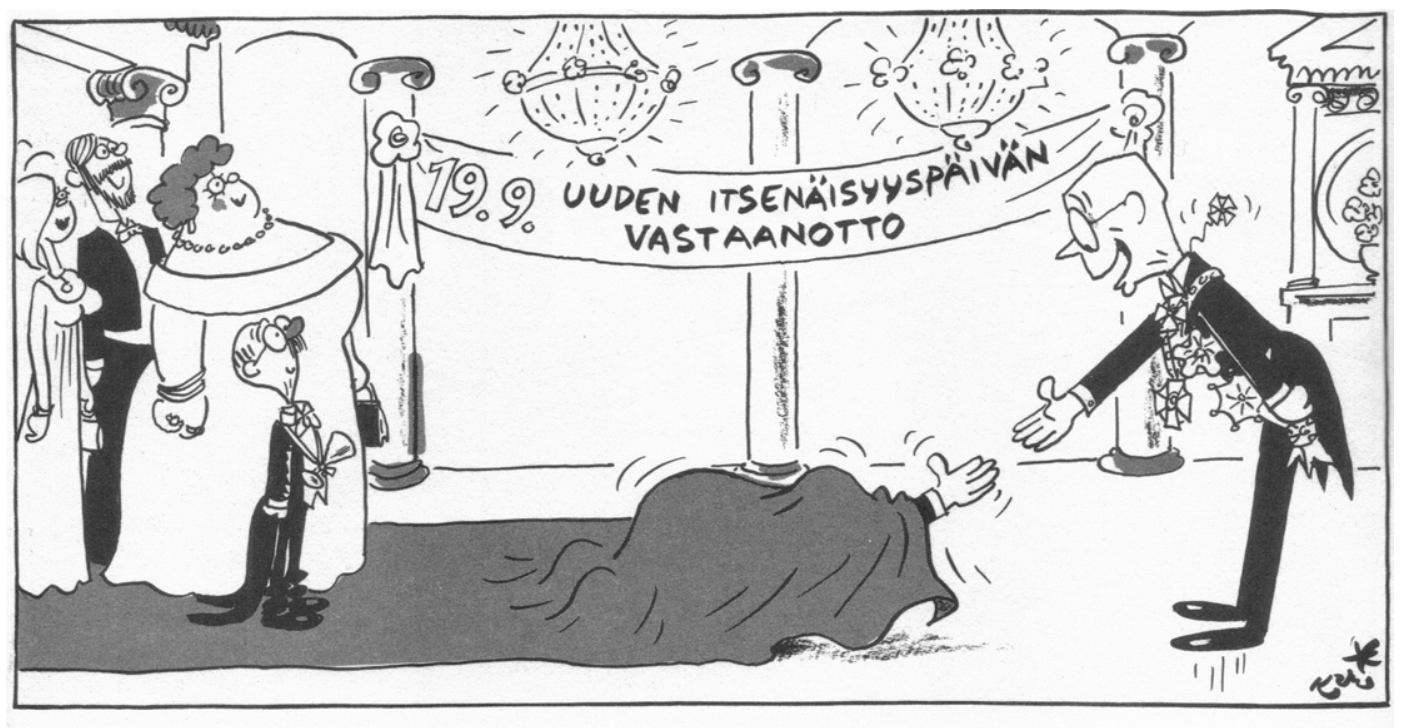

- Ei mutta kas, Uusitalohan se sieltä . . .

Kari arvosteli pilapiirroksissaan pyrkimystä mitätöidä Suomen Neuvostoliiton taholta kokema epäoikeudenmukaisuus. Oheinen piirros kommentoi keskustan Eino Uusitalon ehdotusta muuttaa Suomen itsenäisyyspäivä välirauhansopimuksen solmimispäiväksi. Kuva: HS 17.11.1974.

Yksi Karin piirroksista (Helsingin Sanomat 17.11.1974) kuvaa, miten uutta Suomea rakennettiin idänsuhteiden perustalle. Piirros liittyy Keskustan Eino Uusitalon ehdotukseen ottaa välirauhansopimuksen solmimispäivä uudeksi itsenäisyyspäiväksi (Uola 2006, 27; Vihavainen 1991, 222). Piirros osoittaa, että sota ja sitä edeltänyt aika pyrittiin häivyttämään pois, ja Suomen historia ja todellinen itsenäisyys alkoivat 
pahimmissa historiantulkinnoissa sodan jälkeisestä aikakaudesta. Piirros viittaa kansan syvien rivien suhtautumiseen ehdotukseen. (Uola 2006, 27; Vihavainen 1991, 223.) Edellisen kaltaiset ehdotukset eivät saaneet suurta vastakaikua, mutta piirros kuvaa kuitenkin hyvin uhkaa siitä, että itä alkaisi määritellä suomalaisuutta ja koko kansallista olemassaoloa.

\section{Kekkosen vallankäyttö ja demokratia}

Kekkonen toimi Paavonsalon näkemyksen mukaan presidenttinä yhtä itsevaltaisesti kuin pääministerinä ja otti kaiken irti presidentin valtaoikeuksista venyttäen niitä vielä pitemmälle. Suomi muistutti De Gaullen Ranskaa, viidettä tasavaltaa. Kekkosen valta perustui presidentin vahvoihin valtaoikeuksiin mutta myös hänen henkilökohtaiseen johtamistyyliinsä. (Paavonsalo 1995, 228-229.)

Piirroksissaan Kari kuvaakin Suomen demokraattiseen järjestelmään kohdistuvia paineita ja riskejä. Piirrokset käsittelivät toteutuneita ja toteutumattomia uhkakuvia, joita Karilla oli Kekkosta kohtaan tämän presidenttiaikana; Kari pelkäsi Kekkosen vievän Suomea diktatoriseen suuntaan. Suomi ei muuttunut Kekkosen aikana diktatuuriksi, mutta piirrokset ennakoivat ja näkivät suomettumisen vaikutukset poliittiselle järjestelmälle Kekkosen aikana. Kari ennusti oikein Kekkosen nousun suomalaisen politiikan tärkeimmäksi ohittamattomaksi hahmoksi: Suomen muuttumisen "Kekkoslovakiaksi".

Karin piirroksissa demokraattisen järjestelmän ongelmat kietoutuivat Kekkosen, eduskunnan ja hallituksen keskinäiseen arvovaltaan. Hän arvosteli sitä, että ulkopolitiikan myötävaikutuksella Kekkosen rooli sisäpolitiikassa kasvoi suhteessa muihin keskeisiin instituutioihin. (Tuikka 2007. 216-217, 296, 338; Tarkka 2012, 248.) Puhuttiin "ruoskaparlamentarismista". Kekkonen ohjaili sisäpolitiikkaa 1970-luvulla hyvin avoimesti (Soikkanen 2008, 17, 19).

Yhdessä piirroksistaan (Helsingin Sanomat 22.3.1977) Kari viittaa Kekkosen lausuntoon ulko- ja sisäpolitiikan suhteesta. Maaliskuussa 1977 Kekkosen luokse Tamminiemeen ilmaantui kaikkiaan seitsemän puolueen puheenjohtajat, ja he pyysivät presidenttiä asettumaan ehdokkaakseen vuoden 1978 presidentinvaaleissa. Kekkonen ilmoitti suostumuksensa, kiitti poliittisia johtajia ja kertoi päätöksensä perusteista: "Minä joskus puolileikilläni tai kokonaan leikilläni sanoin, että jos maassa pitää jonkin asian olla rempallaan, niin olkoon se sitten sisäpolitiikka. Pääasia on vain, ettei se ole ulkopolitiikka. Ja näin asianlaita kieltämättä on, vaikka vähän rankanpuoleisesti tuli sanotuksi". (Porvali 1999, 111.)

Karin piirros pelkistää Kekkosen aikakauden. Se liittyy Kosyginin valtiovierailuun 1970-luvun puolivälissä, jolloin elettiin öljykriisin aikaa. Kari yhdistää ajankohtaiset talousongelmat Kekkosen lausuntoon ja kuvaa Suomen ulkopoliittista myötäilyä ja sisäpolitiikan väistymistä sen eduksi. Piirros symboloi Suomen ja Neuvostoliiton suhteita, kun sisäpoliittinen tilanne jäi idänsuhteiden varjoon ja oli riippuvainen ulkopolitiikasta.

Kekkonen näki ja ymmärsi Neuvostoliitto-keskeisen sodanjälkeisen aikakauden synnyn ja hyödynsi uutta poliittista tilannetta. Hänellä oli paljon poliittisia vastustajia, ja hän ei ollut suuri kansansuosikki 1950-luvulla (Porvali 1999, 78; Suomalainen 1985, 62). Tämä näkyi myös Karin piirroksissa, sillä ne heijastelivat omaa aikaansa, mutta niiden taustalla oli myös Karin henkilökohtainen epäluottamus Kekkosta kohtaan. Kekkonen oli värikäs poliitikko, ja hänestä tuli poliittisen huumorin suosikkihenkilö (Tuikka 2007, 204; Meinander 1999, 299.) Kari otti Kekkosen keskeiseksi henkilöhahmoksi piirroksiinsa jo 1950-luvun alussa. Suomessa oli tuolloin tapana, että tasavallan presidentistä ei tehdä pilakuvia (Porvali 1999, 78-79; Suomalainen 1985, 62). 


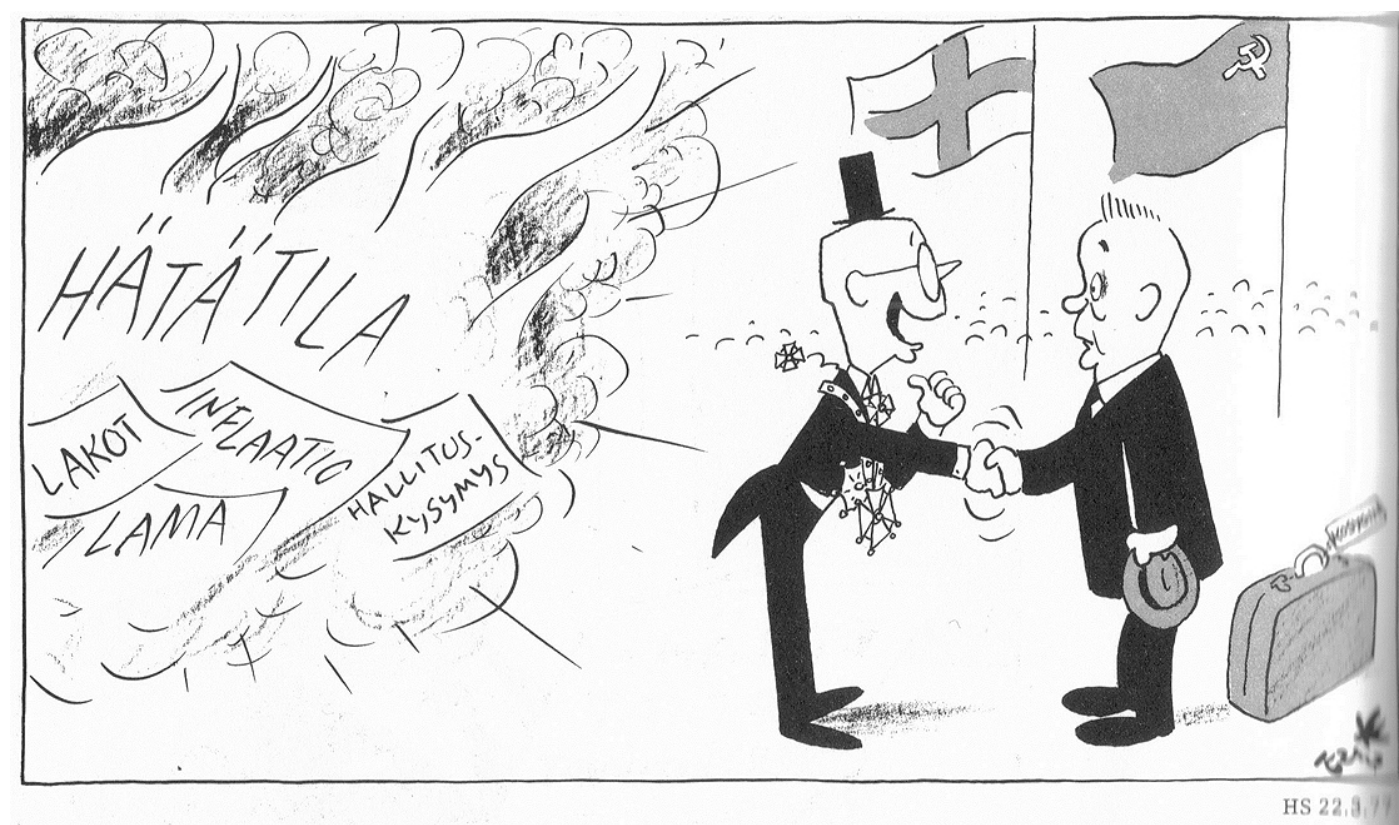

- Hehheh, kuten leikillisesti joskus olen sanonut että jos jonkin on oltava rempallaan niin olkoon se sitten sisäpolitiikka.

Kekkosen aikana ulkopolitiikan merkitys korostui sisäpolitiikan kustannuksella. Kuva: HS 22.3.1977.

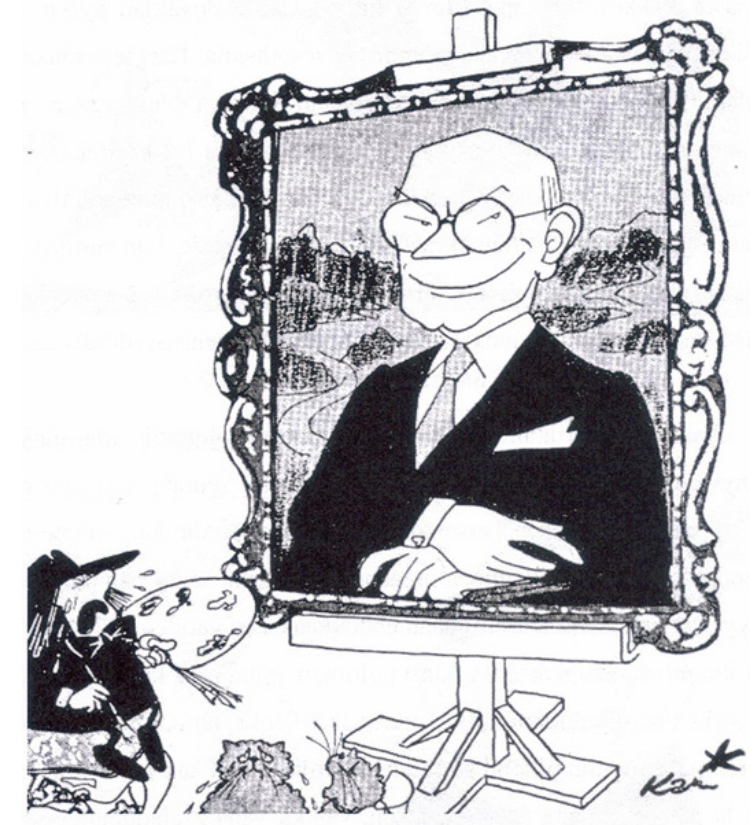

- Miltäkö minusta tuntuu?

Aivan kuten miehestä, joka on menettänyt kultakaivoksen.
Karin 1956 pilapiirroksen presidentiksi valitusta Kekkosesta piti olla viimeinen, sillä aiemmin presidentit eivät toimineet Suomessa pilapiirrosten kohteina. Kuva: HS 17.12.1956.

Helsingin Sanomissa 17.2.1956 julkaistu piirros onkin Karin jäähyväiset Kekkoselle tämän tultua valituksi presidentiksi. Siinä Kari on maalannut presidentin muotokuvan, jossa hän vielä viimeisen kerran pääsee kertomaan mielipiteensä. Hän kuvaa Kekkosen tyypilliseen 1950-luvun tapaansa ivallisena ja vallanhimoisena. 
Piirroksessa Kari itkee menettäneensä kultakaivoksen Kekkosen valinnan myötä. Kari kuitenkin rikkoi vähän ajan kuluttua tabun, jonka mukaan presidentistä ei saa tehdä pilapiirroksia, ja otti Kekkosen jälleen käsittelyn kohteeksi. Kari sanoi Kekkosen tyylinsä mukaisesti suorastaan tarjonneen kalikoita pilapiirtäjän käteen, ja niin riemuralli alkoi taas. (Porvali 1999, 79; Suomalainen 1985, 62.)

Karin piirroksissa Kekkonen ei näyttäydy aivan diktaattorina mutta diktatorisena hahmona kuitenkin, itsevaltiaana demokratian antamissa rajoissa. Kari ei hyväksynyt Kekkosen viehtymystä itsevaltaiseen vallankäyttöön, ja hän kuvasi Kekkosen vallantäyteisenä hahmona. Kekkonen hallitsi valtaoikeuksien ohella epävirallisella arvovallallaan, ja valta keskittyi vähitellen yhä enemmän hänelle (Tuikka 2007, 294-295; Tarkka 2012, 249). Kari esittikin Kekkosen usein monarkin tai diktaattorin roolista haaveilevana, ja hän varoitti demokratian vaarantumisesta suomettumisen rapauttaessa kansanvallan perinnettä (Tuikka 2007, 299). Hänen piirrostensa Kekkosta saattoi verrata valistuneisiin itsevaltiaisiin, sillä Kekkonen edusti valistusajan ihanteita sivistyneenä, valtion kehittämisestä laajasti kiinnostuneena henkilönä (Suomi 2010, 334-335; Tuikka 2007, 215-216). Piirroksissa Kekkonen kuvataan voimahahmona, viimeisenä ratkaisijana, joka "runnoo" päätökset läpi. Niissä Kekkonen on usein takapiruna hallitusneuvottelujen taustalla. Piirrokset kuvaavat, miten Kekkosen arvovalta antoi hänelle mahdollisuuden aktiiviseen presidenttiyteen. Johtajuuden varjopuoli oli suomettumiselle hedelmällinen yhteiskunta.

Karin piirrokset antavat kuvan, että Kekkonen hiljaisesti hyväksyi suomettumisen kulttuurin kehittymisen. 1970-luvun piirroksissa suvereeni ja voimakas Kekkos-hahmo ylhäisessä yksinäisyydessä symboloi suomettumisen aikakautta. Karin presidentinvaaleja käsittelevissä piirroksissa näkyivät selvästi järjestelmän ongelmat. Karista tuli yksi kiivaimmista Kekkosen presidenttiyden vastustajista. Hän puolusti demokratiaa ja vapaita vaaleja sekä kansan todellista valtaa vaikuttaa presidentin valintaan. Karin piirrokset nostavat esiin vuoden 1962 presidentinvaalit taitekohtana Suomen politiikassa. Kekkonen ei halunnut osallistua vuoden 1974 presidentinvaaleihin.

Karin piirrokset kuvaavat, miten puolueiden ulkopoliittinen konsensus mahdollisti Kekkosen kauden jatkamisen lähes yksimielisesti. Karin piirroksissa presidentinvaalien tila symboloi suomettumista, sen räikeää demokraattisten perinteiden ja arvojen hylkäämistä. Politiikka oli yhden miehen show, kun - sanontaa lainaten - "presidentit olivat Kekkosia". Ironista oli, että Karin piirrokset tahattomasti pitivät yllä kuvaa Kekkosesta miehenä, johon aika ei vaikuta. Karin hahmothan eivät vanhentuneet, vaan ne esiintyivät loppuun asti siinä muodossa kuin alussakin.

Eräässä piirroksessaan (Helsingin Sanomat 4.2.1978) Kari pilkkaa puolueiden yksimielistä Kekkos-palvontaa. Piirros kritisoi konsensuksen vaikutusta demokratialle. Se liittyy vuoden 1978 presidentinvaaleihin, jolloin Kekkonen näytti olevan kaikkien puolueiden ehdokas (Suomi 2010, 658-659; Meinander 1999, 440; Porvali 1999, 110). Piirros symboloi puolueiden ja Kekkosen suhdetta. Hänen jatkonsa oli selviö. (Meinander 1999, 440; Porvali 1999, 111.) Piirroksessa tutuilla puoluehahmoilla on kaikilla Kekkosen kasvot Karin verratessa ironisesti Kekkos-konsensusta kansalliseen eheyttämiseen, 1930-luvun politiikkaan ja Kekkosen rooliin siinä. Karin piirroksissa suomalaista demokratiaa presidentinvaaleissa oli se, että Kekkonen suostui ylipäätään vaaleihin.

Kekkosesta oli luotu myytti teräskuntoisena miehenä, ja hänen julkisuuskuvaansa vaalittiin tarkoin. Kekkosen todellista kuntoa salailtiinkin 1970-luvun loppupuolelta lähtien, ja tiedotusvälineet pidettiin pimennossa tai itsesensuurin avulla hiljaa. (Tarkka 2012, 375-376; Paavonsalo 1995, 228, 257.) Julkisuudessa korostettiin Kekkosen urheilullisuutta. Hänen uskottiin olevan vielä 1980-luvun alussa edelleen hyvässä kunnossa. Yksi Karin piirroksista (Helsingin Sanomat 18.1.1981) kuvaa Kekkosen 


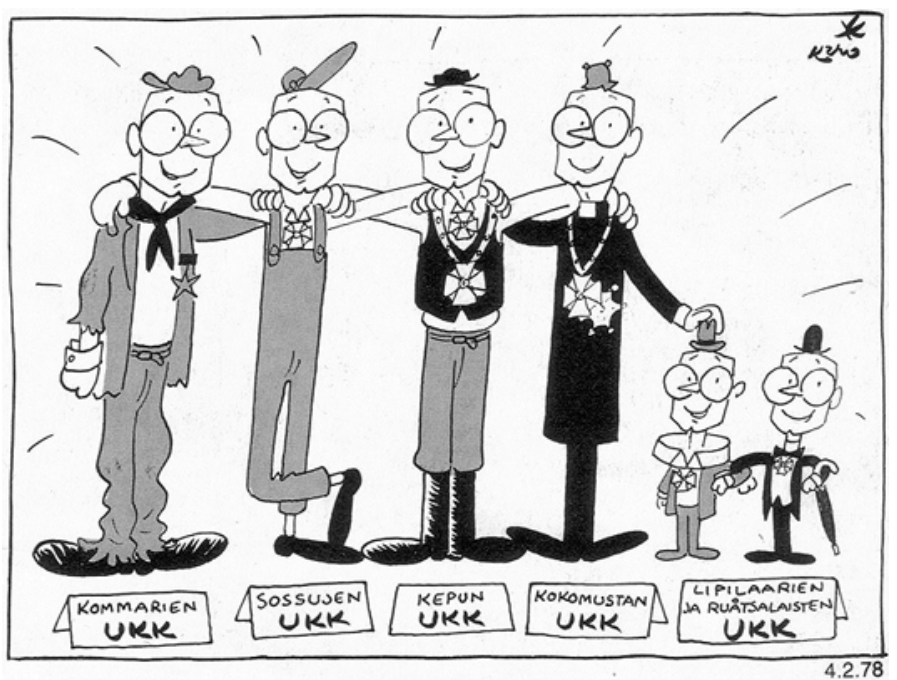

- Olen aina korostanut kansallista eheyttämistä. Katsokaa miten hyvässä sovussa minäkin elän.
Vuoden 1978 presidentinvaaleissa kaikki "presidentit olivat Kekkosia". Kuva: HS 4.2.1978.

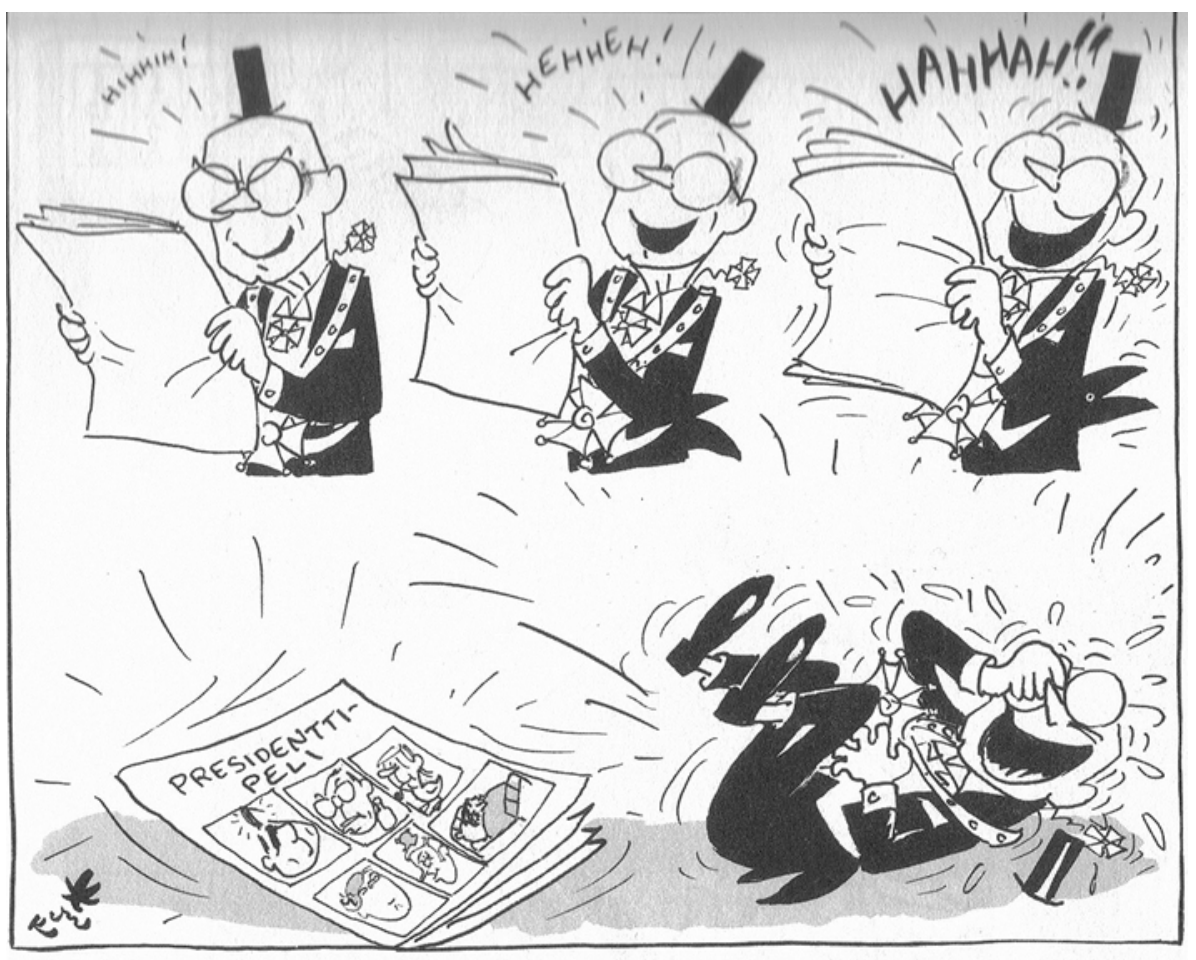

HS 18.1 .81

Vielä vuoden 1981 pilapiirroksessa Kekkonen nauraa katketakseen mahdollisille seuraajaehdokkailleen. Kuva: HS 18.1.1981.

seuraajasta käytyä julkista keskustelua ja antaa ymmärtää, että Kekkonen tulee pysymään vielä pitkään Suomen politiikan johtohahmona. Kari ei osannut ennakoida Kekkosen kunnon romahdusta, eikä hän muiden lailla ymmärtänyt Kekkosen kauden olevan jo lopuillaan. Piirroksessa Kekkonen nauraakin katketakseen mahdollisille seuraajaehdokkaille. (Niiniluoto 1990, 43-44.) Se on julkaistu tammikuussa 1981, syksyllä Kekkonen erosi. 


\section{Hevonen ja leijona}

Kari käsitteli Suomen ulkopoliittista linjaa ja riippuvuutta Neuvostoliitosta kriisien kautta. Yöpakkaskriisi, noottikriisi ja Tšekkoslovakian kriisi kertoivat piirroksissa epävarmuudesta ulkopoliittisen linjan suhteen. Hän toi esiin Suomen puolueettomuuspolitiikan realiteetteja ja Suomi-kuvaa maailmalla. Puolueettomuuden ihanne ja todellisuus eivät kohdanneet. Idänsuhteiden ensisijaisuus ulkosuhteiden hoidossa sai kritiikkiä. Ulkopolitiikan hyödyntämistä ja puolueiden asemaa Kari käsitteli sisäpolitiikan yhteydessä. Ulkopoliittinen diskriminointi johti Kekkosen vallan varmistumiseen puolueiden alistuessa hänen ohjaukseensa ulkopoliittisen konsensuksen kautta. Yhteiskunnallinen ilmapiiri näyttäytyy piirroksissa isänmaallisuuden, itsesensuurin ja poliittisen kulttuurin muutoksen muodossa. Piirrokset kiinnittivät huomiota demokraattisen järjestelmän toimivuuteen ja demokraattisten periaatteiden kunnioitukseen Kekkosen johtajuuden ja presidentinvaalien pohjalta.

Karin piirroksia kannattaa tarkastella siinä valossa, että aikana, jolloin elettiin niin kutsutussa Kekkosen Suomessa, oli kuitenkin itsesensuurin kuristamassa mediassa mahdollisuus esittää Kekkos-kriittistä sisältöä. Karin pilapiirrokset siis - pelkän ajankuvan lisäksi - osoittavat, kuinka Kekkosen valtakauden hallitseva totuus onnistuttiin haastamaan. Niiden kautta voitiin muokata yleisön mielipidettä. Sananvapaus on olemassa oikeastaan vain silloin, kun sitä käytetään. Karin pilapiirrokset symboloivat jo itsessään länsimaisen journalismin ihanteita. Karin pilapiirrokset kertovat Kekkos-kritiikin eläneen mediassa suomettumisen ja itsesensuurin mustimpinakin hetkinä. Helsingin Sanomat tarjosi kuville mielipidekanavan suojellen Karin mielipidevapautta.

Karin pilapiirrokset voi sitoa osaksi Helsingin Sanomien laajempaa tavoitetta puolustaa läntistä demokraattista journalismia. Helsingin Sanomat halusi sotienjälkeisessä tilanteessa julkaista amerikkalaisia sarjakuvia tuodakseen lukijoidensa saataville länsimaisia arvoja edistävää viihdesisältöä. Lehden halu antaa tilaa omalle pilapiirtäjälle voidaan nähdä tätä taustaa vasten. Kari edusti kansainvälistä pilapiirrosperinnettä ottamalla etenkin uransa alussa mallia ulkomaisilta esikuvilta. Karin piirrokset muistuttivat maailmalla keskeisissä sanomalehdissä julkaistuja päivän piirroksia. Helsingin Sanomille oli sotien jälkeen tärkeää säilyttää yhteys länteen. (Manninen-Salokangas 2009, 513, 521, 551-557.)

Karin piirrokset liikkuivat abstraktilla, käsitteellisellä tasolla (Niiniluoto 1979, 135). Kekkonen esiintyi niissä poliittisena toimijana. Kari oli esittänyt kritiikkinsä Kekkosen ollessa vallassa. Hänen ei tarvinnut liittyä niihin, jotka uskalsivat hyökätä Kekkosta vastaan tämän kuoltua. Kari oli kuin Aisopoksen sadun hevonen, joka ei halunnut potkia kuollutta leijonaa. (Porvali 1999, 138-139; Niiniluoto 1990, 41-42.)

Kekkosen ja Karin suhde oli ristiriitainen, eräänlainen viha-rakkaussuhde. He joutuivat sietämään toisiaan, ja kunnioitus kasvoi vähitellen. Kekkosen hahmo muuttui piirroksissa alkuaikojen konnasta myöhemmin valtiomiesmäiseksi. Kekkonen teki Karista professorin ja kutsui tämän linnaan. Kekkonen ilmeisesti jopa pyysi Karia iltapalalle Tamminiemeen. Kari ei mennyt. (Porvali 1999, 112,137.) Kekkonen omisti useita Karin alkuperäispiirroksia, yksi peräti hänen vuoteensa vieressä (Niiniluoto 1990, 42).

Voidaan sanoa, että kaiken jälkeen Kekkonen ja Kari lopulta hyötyivät toisistaan. Suhde oli eräällä lailla symbioottinen. Kansa tykästyi Karin piirrosten itsevaltaiseen presidenttihahmoon niin, että Kari kutsui itseään Kekkosen parhaaksi pr-mieheksi (Niiniluoto 1979, 139). Kari myös puolusti olemassaolollaan sananvapautta ja osoitti, että itsesensuurista huolimatta Suomi ei ollut Kekkosen diktatuuri. Näin Karin voi nähdä edesauttaneen Kekkosen pyrkimystä rakentaa maailmalla kuvaa Suomesta puolueettomana länsimaisena demokratiana. Kekkonen tarjosi Karille ehtymättö- 
mästi aiheita. Kansa rakasti Kekkosta uhmaavaa piirtäjää (Porvali 1999; Niiniluoto 1990, 18).

Kari ja Kekkonen olivat kaksi oman alansa suvereenia hallitsijaa. Kekkosen sanontaa lainaten, he olivat liha toistensa piikeissä. Pilapiirroksessa esiintyminen on perinteisesti nähty suurena kunniana, sillä niitä tehdään vain suurista poliitikoista. Näin voidaan nähdä myös Karin Kekkos-piirrokset: ne olivat kunnianosoitus kohteelleen. Urho Kekkonen sai arvoisensa pilapiirtäjän. Kari ja Kekkonen olivat kaksi kuningasta.

\section{Tutkimuskirjallisuus}

Häikiö, Martti (2008) Historia ja väärät profeetat: Kirjoituksia Suomen historian kipupisteistä. Helsinki: Edita. Laqueur, Walter (1980) The Political Psychology of Appeasement: Finlandization and Other Unpopular Essays. Piscataway New Jersey: Transaction Publishers.

Manninen, Ohto \& Salokangas, Raimo (2009) Eljas Erkko: Vaikenematon valtiomahti. Helsinki: WSOY.

Maude, George (1976) The Finnish Dilemma: Neutrality in the Shadow of Power. Oxford: Oxford University Press.

Meinander, Henrik (2012) Tasavallan tiellä: Suomi kansalaissodasta 2000-luvulle. Helsinki: Schildts \& Söderströms.

Mouritzen, Hans (1988) Finlandization: Towards a General Theory of Adaptive Politics. Aldershot: Avebury.

Navasky, Victor S. (2013) The Art of Controversy: Political Cartoons and Their Enduring Power. New York: Alfred A. Knopf.

Nevakivi, Jukka (1996) Miten Kekkonen pääsi valtaan ja Suomi suomettui. Helsinki: Otava.

Niiniluoto, Maarit (1979) Ihmisen ääni. Helsinki: WSOY.

Niiniluoto, Maarit (1990) Karin ääni. Helsinki: WSOY.

Paavonsalo, Matti (1995) Kekkosen valta. Helsinki: Gummerus.

Porvali, Seppo (1999) Tasavallan hovinarri: Dokumentti maailman parhaimpiin pilapiirtäjiin kuuluneen Kari Suomalaisen elämästä. Tampere: Revontuli.

Reimaa, Markku (2013) Diplomatian taikuri: Ralph Enckell. Helsinki: Edita.

Rentola, Kimmo (1997) Niin kylmää, että polttaa: Kommunistit, Kekkonen ja Kreml 1947-1958. Helsinki: Otava.

Rivers, Kenneth T. (1991) Transmutations: Understanding Literary and Pictorial Caricature. Lanham: University Press of America.

Salminen, Esko (2004) Viestinnällä vallankumoukseen: "Demokraattisen toimittajakoulutuksen" aika 1960-luvulta 1980-luvulle. Helsinki: Edita.

Seppinen, Jukka (2004) Urho Kekkonen: Suomen johtaja: poliittinen elämäkerta. Helsinki: Ajatus Kirjat.

Seppänen, Esa (2004) Miekkailija ja tulivuori: Urho Kekkonen ja Nikita Hruštšov 1955-1964. Helsinki: Tammi. Seppänen, Esa (2009) UKK:n syvä jälki: Perintö vai painolasti. Helsinki: Ajatus Kirjat, Gummerus Kustannus.

Soikkanen, Timo (2003) Presidentin ministeriö: Ulkoasiainhallinto ja ulkopolitiikan hoito Kekkosen kaudella I: Kansainvälistymisen ja muutosvaatimusten paineessa 1956-1969. Helsinki: Ulkoasiainministeriö.

Soikkanen, Timo (2008) Presidentin ministeriö II: Ulkoasiainhallinto ja ulkopolitiikan hoito Kekkosen kaudella II: Uudistumisen, ristiriitojen ja menestyksen vuodet 1970-1981. Helsinki: Otava.

Suomalainen, Kari (1985) Maxi - Kari: 1000 piirrosta vuosilta 1951-1985. Helsinki: Otava.

Suomi, Juhani (1992) Kriisien aika: Urho Kekkonen 1956-1962. Helsinki: Otava.

Suomi, Juhani (2010) Lohen sukua: Urho Kekkonen. Poliitikko ja valtiomies. Helsinki: Otava.

Tarkka, Jukka (2012) Karhun kainalossa: Suomen kylmä sota 1947-1990. Helsinki: Otava.

Uola, Mikko (2006) Itsesensuurin kritiikkiä: Tekstejä suomettumisen vuosista Neuvostoliiton hajoamiseen. Turku: Turun yliopiston digipaino. 
Vihavainen, Timo (1991) Kansakunta rähmällään: Suomettumisen lyhyt historia. Helsinki: Otava.

Visuri, Pekka (2006) Suomi kylmässä sodassa. Helsinki: Otava.

Ylönen, Marja (1998) Karin Suomi: Karin piirrokset suomalaisuuden kuvana. Helsinki: WSOY.

Ylönen, Marja (2001) Pilahistoria: Suomi poliittisissa pilapiirroksissa 1800-luvulta 2000-luvulle. Helsinki: Suomalaisen Kirjallisuuden seura. 